\title{
SOSIALISASI BAHAYA COVID-19 DAN PROTOKOL KESEHATAN KEPADA ANAK-ANAK DI TEMPAT LES DESA SIDORAHAYU
}

\author{
Novita Diana Lestari \\ Program Studi Pendidikan Sejarah, Fakultas Ilmu Sosial, \\ Universitas Negeri Malang \\ Jalan Semarang, No 5, 65145 \\ E-mail: novita.tgs@gmail.com
}

Submitted: 11 Desember Accepted: 23 April 2021 Published: 30 April 2021

\begin{abstract}
Abstrak: Artikel ini bertujuan untuk mengetahui pemahaman anak-anak dan juga penerapan protokol kesehatan pada saat pelaksanaan kegiatan sosialisasi. Metode yang digunakan dalam artikel ini adalah dengan praktik secara langsung kepada anak-anak dan juga dengan menggunakan beberapa sumber pustaka berupa artikel mengenai COVID-19 yang merupakan wabah yang telah menyebar ke berbagai negara di dunia, tidak terkecuali Indonesia. Penyebaran COVID-19 di Indonesia terus mengalami lonjakan karena kurangnya kesiapan pemerintah dalam mencegah persebaran COVID-19. Dengan adanya lonjakan yang terus terjadi kemudian pemerintah Indonesia mengeluarkan kebijakan Pembatasan Sosial Beskala Besar (PSBB). Dampak dari persebaran virus yang melonjak ini dirasakan oleh berbagai bidang kehidupan, salah satunya yaitu bidang pendidikan. Kegiatan belajar mengajar harus dilakukan secara daring dari rumah untuk mencegah persebaran COVID-19. Dengan peserta didik yang melakukan kegiatan belajar dirumah inilah kemudian kegiatan sosialisasi dilakukan di tempat les yang pada saat ini menjadi pilihan orang tua dalam membantu proses belajar sang anak.
\end{abstract}

Kata Kunci : sosialisasi, COVID-19, protokol kesehatan 


\section{PENDAHULUAN}

Penyebaran virus corona telah merambah ke berbagai negara yang ada di dunia sejak bulan Desember 2019. Virus ini memberikan dampak besar bagi berbagai sektor yang ada di seluruh dunia. Coronavirus masih satu keluarga dengan virus $S A R S$ dan $M E R S$ yang sebelumnya telah menyerang berbagai negara di dunia. Akan tetapi Coronavirus Diseases 2019 atau yang biasa disebut dengan COVID-19 ini sebelumnya belum pernah ditemukan maupun teridentifikasi dalam tubuh manusia sehingga merupakan penyakit jenis baru (Dewi, 2020). Pertama munculnya virus ini terjadi di Wuhan, Tiongkok yang kemudian beberapa negara di dunia juga terdampak oleh virus ini. Persebaran virus ini terjadi begitu cepat dan tidak ada yang mampu memprediksikan kapan tepatnya pandemi ini akan berakhir (Ristyawati, 2020). Gejala umum yang disebabkan oleh COVID-19 ini diantara lain adalah gejala gangguan pernapasan yang akut seperti demam, batuk, dan sesak napas. Lama dari masa inkubasi virus ini adalah lima sampai enam hari dengan masa inkubasi terpanjang selama empat belas hari. Tidak hanya satu negara yang terdampak akan virus ini, berbagai negara di dunia turut merasakan dampaknya sehingga World Health Organization (WHO) menetapkan keadaan darurat kesehatan masyarakat pada tanggal 30 Januari 2020 (Dewi, 2020).

Indonesia mulai mengonfirmasi adanya 2 kasus COVID-19 pada tanggal 2 Maret 2020. Kurangnya kesiapan dalam mencegah persebaran COVID-19 mengakibatkan lonjakan kasus terjadi cepat. Karena tingginya tingkat persebaran yang terjadi, menjadikan pemerintah harus segera mengambil langkah dan menetapkan kebijakan guna mengatasi dampak dari COVID-19. Presiden Jokowi kemudian mengumumkan pernyataan mengenai kebijakan yang dipilih yaitu Pembatasan Sosial Berskala Besar (PSBB) pada tanggal 31 Maret 2020. Dalam konferensi pers yang dilakukan oleh Presiden Jokowi, beliau menegaskan bahwa kebijakan Pemerintah Daerah harus sesuai dan tunduk pada PSBB yang telah ditetapkan oleh Pemerintah Pusat (Dewi, 2020). Pembatasan sosial berskala besar ini dilakukan dalam upaya memutus rangkaian penyebaran dari COVID-19. Pemberlakuan PSBB dalam penerapannya membatasi masyarakat untuk berkumpul, sehingga baik pekerjaan maupun pendidikan serta bidang lain dilakukan 
pembatasan dengan tidak melakukan kegiatan di luar dengan pemerintah menyarankan untuk tetap berada di rumah. Selain pemberlakuan PSBB pemerintah juga melakukan kebijakan lockdown yang menghimbau seluruh kegiatan dilaksanakan dirumah. Pemberlakuan lockdown merupakan suatu upaya untuk mencegah penyebaran virus corona di suatu wilayah, yang kemudian diharapkan dengan pemberlakuan kebijakan ini suatu masyarakat yang berada salam suatu wilayah dapat terhindar dari virus corona (Yunus \& Rezki, 2020).

Dalam bidang pendidikan, pemerintah mengeluarkan Surat Edaran yang berisi kegiatan pembelajaran dilakukan di rumah dengan menggunakan pembelajaran daring atau jarak jauh. Pembelajaran daring atau jarak jauh ini diterapkan kepada semua jenjang pendidikan mulai dari PAUD, TK, SD, SMP, SMA/SMK, hingga perguruan tinggi. Pelaksanaan pembelajaran jarak jauh memiliki dampak di setiap jenjang terutama untuk anak-anak yang masih dibawah umur. Anak-anak ini masih perlu bimbingan secara maksimal. Selain itu anak-anak juga harus diberikan pemahaman mengenai apa yang sedang terjadi, dan apa itu virus corona serta memberikan pemahaman mengenai pentingnya protokol kesehatan.
Berdasarkan uraian ini penulis menarik tiga rumusan masalah yakni 1) dimana dan siapa sasaran penelitian ini, 2) bagaimana pemahaman anak-anak mengenai COVID19, 3) apa pengertian COVID-19 dan juga apa pentingnya protokol kesehatan, 4) bagaimana penerapan protokol kesehatan dan pelaksanaan cuci tangan di tempat les. Pemahaman kepada anak-anak ini sangat penting bagi pengetahuan dan juga untuk menumbuhkan kesadaran mereka dalam melaksanakan protokol kesehatan. Sehingga perlu diadakan sosialisasi mengenai bahaya COVID-19 dan juga pentingnya protokol kesehatan. Oleh karena itu penelitian ini bertujuan untuk mengetahui pemahaman anak-anak mengenai COVID-19 dan juga protokol kesehatan selain itu juga sebagai realisasi pengabdian mahasiswa untuk masyarakat di lingkungan sekitar tempat tinggal.

\section{TINJAUAN PUSTAKA}

\subsection{Bahaya COVID-19}

Virus corona merupakan keluarga besar dari virus yang dapat menyebabkan gejala baik dari ringan sampai berat. Virus corona yang menyebabkan gejala berat ini setidaknya terdapat dua jenis yaitu Middle East Respiratory Syndrome (MERS) dan Severe Acute Respiratory Syndrome (SARS). Selanjutnya terdapat virus baru yaitu Coronavirus Diseases 
(COVID-19) yang sebelumnya belum pernah ditemukan dalam tubuh manusia. Gejala umum dari COVID-19 ini adalah gangguan pernapasan akut, seperti demam, batuk, dan sesak napas. Lamanya masa inkubasi dari virus ini adalalah mulai dari 5-6 hari dengan masa inkubasi terpanjang 14 hari (Dewi, 2020). Penyebab dari penyakit menular ini adalah sindrom pernapasan akut coronavirus 2 (SARSCoV-2). Selain gejala umum yang telah disebutkan, COVID-19 juga mengakibatkan dampak lanjutan yaitu menjadi pneumonia virus serta kegagalan organ (Supriatna, 2020).

Berbagai dampak telah dirasakan berbagai aspek kehidupan masyarakat Indonesia. Penyebaran COVID-19 yang terjadi semakin meluas sehingga pemerintah mengeluarkan kebijakan dengan menerapkan Pembatasan Sosial Berskala Besar (PSBB) yaitu dengan social distancing dan physical distancing yang bertujuan untuk mengurangi mata rantai penyebaran COVID-19. Pembatasan yang dilakukan tidak hanya untuk daerah yang terdampak, akan tetapi juga diterapkan secara nasional (Ahmad, 2020). Penyebaran atau perpindahan COVID-19 memiliki dua cara yaitu dengan percikan (droplet) saluran pernapasan dan kontak. Percikan saluran pernapasan dapat terjadi karena bersin maupun batuk. Resiko terpapar percikan saluran pernapasan ini terjadi jika seseorang berada dalam kontak erat yaitu radius satu meter yang kemungkinan dapat menyebabkan infeksi. Selain itu, percikan juga dapat menempel pada benda sekitar dan virus masih tetap aktif. Oleh sebab itu, lingkungan terdekat atau sekitar orang yang terinfeksi bisa menjadi sumber penularan (penularan kontak). Karena virus ini tidak dapat dilihat dan tidak dapat diketahui seorang yang membawa virus tersebut maka perlu adanya pencegahan yaitu dengan memakai masker, menjaga jarak, dan juga mencuci tangan (Sembiring, dkk, 2020).

\subsection{Pentingnya Protokol Kesehatan}

Memakai masker dapat menjadi salah satu cara dalam mencegah penularan virus corona. Hal ini dikarenakan dengan menggunakan masker maka hidung dan mulut tertutup sehingga dapat mencegah penyebaran virus atau percikan yang akan tersebar. Salah satu jenis masker yang dapat dengan mudah diperoleh serta penggunaannnya cukup efisien adalah masker kain. Masker kain ini dapat digunakan maksimal empat jam yang kemudian harus diganti dengan masker baru dan bersih (Sembiring, dkk, 2020). Pencegahan penyebaran virus corona selanjutnya yaitu dengan cara menjaga 
jarak. Menjaga jarak ini sangat diperlukan karena dengan menjaga jarak dapat meminimalisir percikan virus. Kebijakan pemerintah untuk menjaga jarak ini adalah dengan cara menerapkan Pembatasan Sosial Berskala Besar (PSBB) dan juga lockdown. Berdasarkan nomor 5 tahun 2020 tentang Peniadaan Sementara Kegiatan Peribadatan dan Keagamaan Di Rumah Ibadah Dalam Rangka Mencegah Penyebaran Wabah corona virus disease (COVID-19) kegiatan lockdown menjadi kebijakan Gubernur DKI Jakarta. Selanjutnya deiberikan seruan kepada pelaksana ibadah untuk melakukan kegiatan ibadah di rumah (Yunus \& Rezki, 2020).

Pemberlakuan ini berlangsung selama 14 hari sejak adanya seruan dan dapat diperpanjang jika diperlukan. Dengan adanya lockdown maka dapat mengurangi aktivitas manusia sehingga mencegah resiko penularan yang tinggi (Yunus \& Rezki, 2020). Protokol kesehatan selanjutnya yaitu dengan cara mencuci tangan. Menjaga kebersihan tangan menjadi faktor penting untuk mengatasi penularan virus, karena tangan merupakan salah satu perantara masuknya virus ke dalam tubuh. Cara yang paling sederhana menjaga kebersihan tangan adalah dengan mencuci tangan menggunakan sabun. Dengan praktik mencuci tangan memakai sabun secara tepat merupakan cara termudah dan efektif untuk mencegah penyebaran percikan virus saat mengenai tangan. Semakin berkembangnya zaman dan bertambahnya kesibukan masyarakat maka muncul inovasi produk mencuci tangan tanpa menggunakan air yaitu dengan handsanitizer. Produk handsanitizer mengandung antiseptik sehingga dapat membunuh kuman (Desiyanto \& Djannah, 2013).

\section{METODE PELAKSANAAN}

Lokasi pelaksanaan sosialisasi mengenai COVID-19 dan juga penerapan protokol kesehatan ini dilakukan di salah satu tempat les yang berada di Dusun Losari, Desa Sidorahayu, Kecamatan Wagir, Kabupaten Malang. Tempat les ini merupakan wujud dari inisiatif salah satu mahasiswa Universitas Negeri Malang, sebagai pengisi waktu luang di kala pembelajaran jarak jauh, sehingga sembari kuliah online mahasiswa ini juga mendampingi anak-anak untuk belajar di rumahnya. Murid yang ada di tempat les ini rata-rata adalah anak yang berada di jenjang sekolah dasar dan juga taman kanak-kanak. Yang berjumlah 7 anak yang terdiri dari 2 anak TK, 1 anak kelas 2 SD, 1 anak kelas 4 SD, dan 3 anak dari kelas 5 
SD. Pengabdian masyarakat ini memiliki beberapa tahapan yaitu:

\section{Tahap Persiapan}

Pada tahap ini beberapa kegiatan yang dipersiapkan sebelum melaksanakan pengabdian yautu mengidentifikasi masalah yang ada di sekitar lingkungan desa. Setelah menemukan berbagai masalah yang ada, tahap selanjutnya yaitu memilih satu permasalahan. Setelah menentukan satu masalah kemudian menyusun upaya yang akan dilakukan untuk mengatasi masalah yang dipilih. Setelah itu dilanjutkan dengan pembuatan proposal. Tahap berikutnya dari proposal yang telah selesai adalah pelaksanaan dari upaya untuk memecahkan masalah.

\section{Tahap Pelaksanaan}

Pelaksanaan pengabdian ini diawali dengang perkenalan dan penyampaian tujuan kepada anakanak. Kemudian dilanjutkan dengan pemberian pertanyaan mengenai pemahaman peserta didik terhadap bahaya COVID19. Setelah itu diberikan penjelasan singkat mengenai bahaya COVID-19 dan juga melihat video animasi COVID-
19. Setelah pemahaman materi dilanjutkan dengan praktik langsung untuk cuci tangan.

\section{HASIL DAN PEMBAHASAN}

Karena jarak rumah yang dekat dan juga adanya pembatasan sosial yang berdampak pada pendidikan terutama sekolah, maka orang tua dari anak-anak memasukkan mereka ke tempat les yang dekat dari rumah mereka. Tidak semua orang tua di desa ini memahami dan dapat mengajari anaknya saat mendapat tugas maupun saat melakukan pembelajaran jarak jauh secara online. Selain dikarenakan oleh kedua orangtua yang sedang bekerja, pendidikan orangtua juga mempengaruhi alasan mengapa orang tua memilih untuk memasukkan anak ke tempat les ini. Kegiatan di tempat les ini di mulai pada pukul 7 pagi sampai dengan pukul 11 siang. Sasaran dari penelitian ini adalah anak-anak yang berada di tempat les ini. Hal ini dikarenakan masih terdapat beberapa anak yang kurang memahami COVID-19 dan pentingnya protokol kesehatan, terutama di desa belum ada sosialisasi terkait COVID-19 kepada anakanak. 

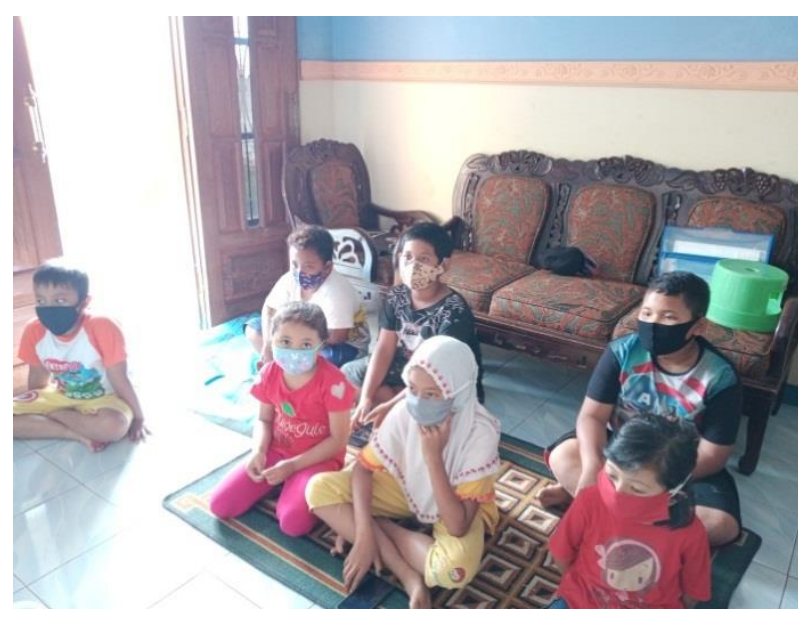

Gambar 1. Peserta didik saat perkenalan.

Sosialalisasi di tempat les yang ada di Dusun Losari ini dilakukan pada hari Rabu, 4 November 2020. Kegiatan sosialisasi dimulai pada pukul 10.15 yaitu setelah kegiatan les selesai. Sosialisasi diawali dengan perkenalan oleh peneliti dan penyampaian maksud serta tujuan dari sosialisasi. Selanjutnya yaitu anak-anak diberikan sebuah pertanyaan sederhana mengenai apa sebenarnya COVID-19 dan bagaimana cara mencegahnya. Beberapa dari anak-anak memberikan jawaban di antaranya: Covid itu berbahaya, Covid itu virus, Covid itu menyebabkan sakit. Selanjutnya yaitu pemberian pertanyaan mengenai bagaimana cara mencegah COVID-19. Beberapa jawaban diantaranya yaitu dengan menggunakan masker, mencuci tangan, menggunakan handsanitizer, dan juga dengan tetap berada dirumah.

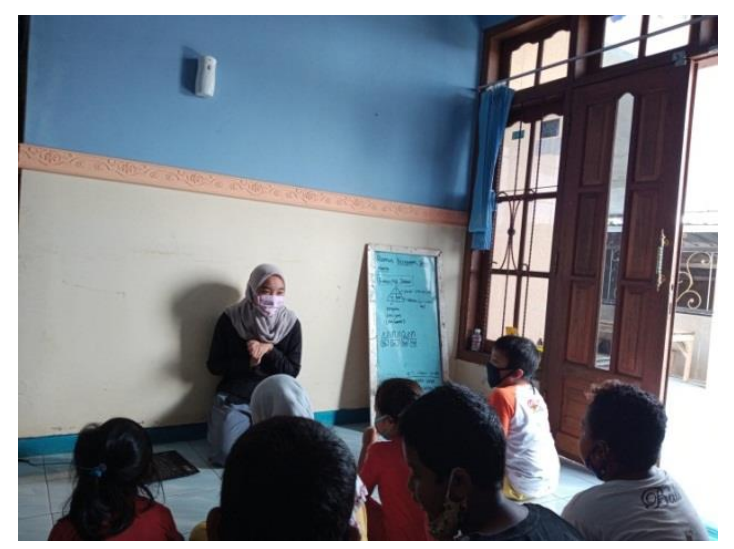

Gambar 2. Pemberian pertanyaan singkat mengenai pemahaman anak-anak terhadap COVID-

19.

Hasil jawaban dari anak-anak dapat disimpulkan bahwa mereka memahami pengertian COVID-19 dan juga mengerti tentang protokol kesehatan secara umum. Akan tetapi, mereka belum mengerti tentang bagaimana virus dapat menyebar dan juga bagaimana protokol bekerja dalam mengatasai penyebaran virus corona. Setelah mengetahui hasil jawaban dari anak-anak, peneliti kemudian memberikan materi singkat tentang COVID-19 dan juga pentingnya protokol kesehatan. Pemberian materi ini diawali dengan penjelasan singkat tentang COVID-19 dan dilanjutkan dengan melihat video animasi penjelasan singkat mengenai virus corona dan bagaimana virus corona dapat menyebar. 


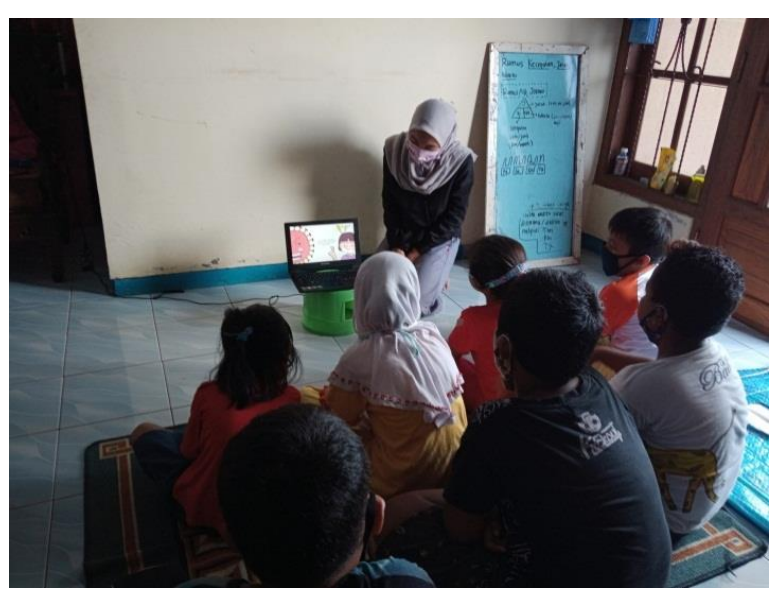

Gambar 3. Melihat video animasi tentang COVID-

19.

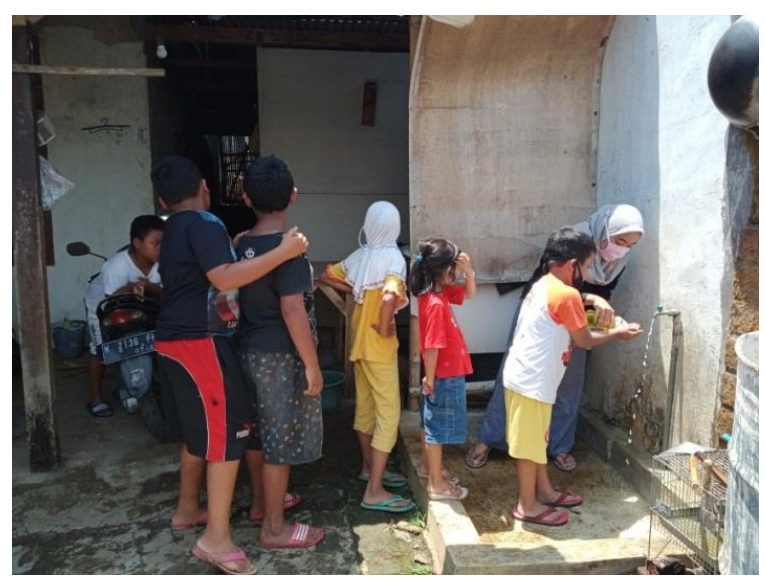

Gambar 4. Pelaksanaan Cuci Tangan

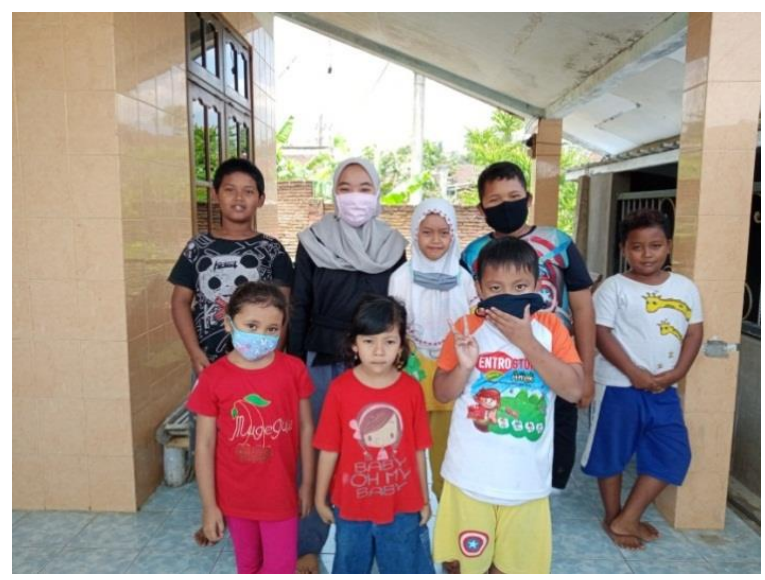

Gambar 5. Dokumentasi foto bersama setelah sosialisasi

Penerapan protokol kesehatan secara langsung dilakukan saat selesai pemberian materi mengenai bahaya COVID-19.
Untuk penerapan penggunaan masker sudah terlaksana saat pemberian materi. Kegiatan selanjutnya yaitu cuci tangan secara bergiliran bersama peserta didik. Cuci tangan ini dilakukan dengan air mengalir serta sabun cuci tangan yang dipraktikkan dengan 7 tahapan mencuci tangan secara benar dengan durasi 20-30 detik.

\section{KESIMPULAN}

Sosialisasi merupakan suatu kegiatan yang ditujukan untuk memberikan manfaat maupun pengetahuan bagi masyarakat dan lingkunagn sekitar. Kegiatan sosialisasi dapat dilakukan secara sederhana terutama bagi seorang mahasiswa yang mempunyai peran dalam membagikan ilmu maupun sumbangasih kepada masyarakat. Kondisi dunia saat ini sedang di hebohkan dengan adanya virus corona. Coronavirus masih satu keluarga dengan virus SARS dan $M E R S$ yang sebelumnya telah menyerang berbagai negara di dunia. Virus ini juga disebut sebagai COVID-19 yang menyerang sistem pernafasan. Dampak dari COVID-19 ini juga dirasakan oleh negara Indonesia dimana persebaran virus terus meningkat sehingga menyebabkan pemerintah Indonesia menerapkan kebijakan sebagai upaya dalam menangani persebaran COVID-19. Dengan adanya hal ini maka sosialisasi dilakukan dengan 
tujuan untuk mengedukasi peserta didik yang juga turut terdampak adanya COVID-19 dimana mereka harus melakukan pembelajaran seara daring di rumah.

Pelaksanaan kegiatan sosialisasi berada di salah satu tempat les di lingkungan sekitar yang saat pembelajaran daring menjadi pilihan bagi orangtua peserta dudik dalam melaksanakan pembelajaran daring. Sosialisasi dimulai dengan pertanyaan singkat mengenai pemahaman anak-anak tentang COVID19. Setelah pertanyaan singkat ini dilanjutkan dengan pemberian materi bahaya COVID-19 secara singkat dan juga dengan melihat video mengenai COVID19. Setelah kegiatan ini dilanjutkan dengan praktik cuci tangan bersama menggunakan air mengalir dan sabun cuci tangan. Pelaksanaan cuci tangan bersama ini mengakhiri kegiatan sosialisasi yang kemudian dilanjutkan dengan dokumentasi foto bersama. Setelah kegiatan sosialiasi ini diharapkan peserta didik memahami bahaya COVID-19 dan juga mematuhi protokol kesehatan dan tidak lupa untuk sering mencuci tangan.

\section{UCAPAN TERIMAKASIH}

Peneliti mengucapkan terimakasih kepada Nova selaku pemilik dari tempat les yang digunakan sebagai praktik kegiatan

\section{DAFTAR PUSTAKA}

Ahmad, I. F. (2020). Asesmen Alternatif Dalam Pembelajaran Jarak Jauh Pada Masa Darurat Penyebaran Coronavirus Disease (COVID-19) Di Indonesia. PEDAGOGIK: Jurnal Pendidikan, 7(1), 195-222.

Desiyanto, F. A., \& Djannah, S. N. (2013). Efektivitas mencuci tangan menggunakan cairan pembersih tangan antiseptik (hand sanitizer) terhadap jumlah angka kuman. Jurnal Kesehatan Masyarakat (Journal of Public Health), 7(2).

Dewi, W. A. F. (2020). Dampak COVID19 terhadap implementasi pembelajaran daring di Sekolah Dasar. Edukatif: Jurnal Ilmu Pendidikan, 2(1), 55-61.

Ristyawati, A. (2020). Efektifitas Kebijakan Pembatasan Sosial Berskala Besar Dalam Masa Pandemi Corona Virus 2019 oleh Pemerintah Sesuai Amanat UUD NRI Tahun 1945. Administrative Law \& Governance Journal, 3(2), 240-249.

Sembiring, R., \& Suryani, D. E. (2020). Sosialisasi Penerapan Protokol Kesehatan di Masa Pandemi Dengan Pembagian Masker Kesehatan Kepada Para Pedagang dan Pengunjung Pasar Tradisional Pajak Sore Padang Bulan. Jurnal Abdimas Mutiara, 1(2), 124-130.

Yunus, N. R., \& Rezki, A. (2020). Kebijakan Pemberlakuan Lockdown Sebagai Antisipasi Penyebaran Corona Virus COVID-19. Salam: Jurnal Sosial dan Budaya Syar-i, 7(3), 227-238. 